journal homepage: http://chimie-biologie.ubm.ro/carpathian_journal/index.html

\title{
CHITOSAN/CUMIN (CUMINUM CYMINUM L.) ESSENTIAL OIL EDIBLE BIODEGRADABLE COATING: ITS EFFECT ON MICROBIAL, PHYSICAL AND SENSORY PROPERTIES OF CHICKEN MEAT DURING REFERIGERATION
}

\author{
Fatimeh Shahvandari ${ }^{1}$, Gholamreza Jahed Khaniki ${ }^{1 凶}$, Nabi Shariatifar ${ }^{1}$, Maryam \\ Mahmoudzadeh ${ }^{2}$, Mahmood Alizadeh Sani ${ }^{1}$, Mahsa Alikord ${ }^{1}$, Ramin Nabizadeh ${ }^{1}$ and Abolfazl \\ Kamkar $^{3}$ \\ ${ }^{1}$ Division of Food Safety and Hygiene, Department of Environmental Health Engineering, School of Public \\ Health, Tehran University of Medical Sciences, Tehran, Iran. \\ ${ }^{2}$ Department of Food Sciences and Technology, Faculty of Nutrition and Food Sciences, Tabriz University of \\ Medical Sciences, Tehran, Iran. \\ ${ }^{3}$ Department of Food Hygiene and Control, Faculty of Veterinary Medicine, University of Tehran, Tehran, Iran. \\ $\otimes_{\text {ghjahed@sina.tums.ac.ir }}$ \\ https://doi.org/10.34302/crpifst/2021.13.1.7

\begin{tabular}{l} 
Article history: \\
Received: \\
$\quad 8$ February 2020 \\
Accepted: \\
\multicolumn{1}{c}{ 1 January 2021} \\
\hline Keywords: \\
Chicken meat; \\
Cumin essential oil; \\
Chitosan; \\
Microbial count; \\
Coating.
\end{tabular} \\ Article history: \\ 8 February 2020 \\ 1 January 2021 \\ Keywords: \\ Chicken meat; \\ Cin essential oil \\ Microbial count, \\ Coating.
}


aspects and even dangerous. Nevertheless, the main concerns usage of these materials for food packaging includes the environmental pollution, non-degradability and environmental incompatibility, the migration of compounds from packaging to product, which can be endanger for safety of products and consumer health (Tharanathan, 2003). Therefore, finding materials and methods on new packaging, has attracted greatly for researchers. So, edible, biodegradable and friendly environmentally films for coatings are a new attitude (AlizadehSani et al., 2020; Bagheri, et al., 2019). Edible coatings and films have been proposed as an appropriate packaging due to cheapness, biodegradability, environmental compatibility, nutritional value, renewable potential (AlizadehSani et al., 2018; Noshirvani et al., 2018). Also, films and edible coatings are suitable carriers for additives and antimicrobial compounds, enzymes, preservatives, etc (Azizi-lalabadi et al., 2020; Salari et al., 2018; Sani et al., 2017). As well as biodegradable coatings and films, mainly made of natural compounds, such as proteins, lipids and polysaccharides alone or in combination with other compounds. Therefore, to use of films and coatings composite will promote achieving coating features beside that the keeping properties of the maintained products (Azlin-Hasim et al., 2018).

Chicken as a perishable product, is used throughout the world because of its reasonable cost and its high nutritional values (Chouliara et al., 2007). Fresh chicken is mainly stored at a refrigerated temperature and is freshly consumed $\left(2-5^{\circ} \mathrm{C}\right)$. While, microbial decay or oxidative rancidity are the main reasons the spoilage of these products. It will be worthy to improve new processing and packaging solutions to prolong shelf life of the poultry products (Babuskin et al., 2014). Hence, it is recommended to apply natural food preservatives such as essential oils, chitosan, nisin, etc. to be assisted in keeping poultry from spoilage and pathogenic microorganisms, because of these compounds have low processing side effects on the products (Petrou et al., 2012). So, it is recommended that use the polysaccharides, such as Chitosan (Ch), is considered as an excellent biopolymer, for biodegradable and edible films and coatings composite due to its non-toxic, biodegradable, biocompatible, antimicrobial properties and commonly regarded as a safe food additive $(\mathrm{Xu}$ et al., 2005). Chitosan is a cationic polysaccharide consisting of (1, 4)-linked-2amino-deoxy-b-D-glucan, and is the deacetylated form of chitin (Petrou et al., 2012; Siripatrawan et al., 2012; Yuan et al., 2016). Chitosan is recognized as Generally Recognized as Safe (GRAS) by FDA and possess good antimicrobial properties against wide range of microorganisms (Rhim et al., 2006; Yuan, et al., 2016). Also, it has antioxidant activity that prevents of lipid oxidation and acting as a secondary natural antioxidant for product keeping (Yuan et al., 2016). Chitosan films are suitable system to be used as active compounds carriers (Rhim et al., 2006; Yuan et al., 2016). Many studies reported the benefits of Ch have being applied either individually or in combination with other compounds such as essential oils in food systems. Giatrakou et al. (2010) extended cooked chicken shelf-life by using of $\mathrm{Ch}$ and thyme oil (Giatrakou et al., 2010). Also, Vasilatos et al. (2013) demonstrated the effects of $\mathrm{Ch}$ or rosemary oil, singly or combined, to prolong the shelf-life of turkey meat (Vasilatos et al., 2013); while Petrou et al. (2012) studied Ch dipping or oregano oil, individually or combined, on modified atmosphere packaged chicken breast meat (Petrou et al., 2012).

With this attitude, EO can be considered as a good additive for production of combined chitosan films. EOs, as a natural additive, have antibacterial, antioxidant, antiviral and antifungal activities (Kedia et al., 2014; Petrou et al., 2012; Sani et al., 2017). The most important characteristic of an EO is bactericidal or bacteriostatic properties against a broad range of microorganisms and/ or preventing the oxidation process (Ribeiro-Santos et al., 2017). Cumin also, is an annual herb that belongs to the family Apiaceae. It used extensively and afterward black pepper, is known as the second 
commonly used spice in the world (Kedia et al., 2014; Ruby et al., 2012). Cumin is native to Iran, Egypt, Turkistan and East Mediterranean, China, India, Morocco, South Russia, Japan, Indonesia, Algeria and Turkey (Ruby et al., 2012). CEO seed exhibits antibacterial, antioxidant properties (Jirovetz et al., 2005; Kedia et al., 2014).

Based on what was said, the application of $\mathrm{Ch}$ with CEO, has not been reported to date, in fresh chicken meat. Thus, the purpose of this study was to evaluate the effects of $\mathrm{Ch}$ and $\mathrm{CEO}$, applied individually or simultaneous combination use of physicochemical, microbiological and sensory properties of chicken breast meat during refrigeration.

\section{Materials and methods}

\subsection{Chicken meat}

Fresh chicken breast fillet meat was purchased from a local poultry processing company. Samples were transferred to the laboratory using insulated polystyrene boxes on ice flasks and then were divided (ca.220 g or $16 \mathrm{~cm} \times 8 \mathrm{~cm}$ for each sample). Chicken meat samples were kept at refrigerated temperature for other tests.

\subsection{Preparation of chitosan coating solution}

Low molecular weight chitosan powder (MW; 340) with moisture content less than 10\% and a deacetylation degree of $75-85 \%$ (Manufacturer's data) obtained from crab shells was purchased from Sigma Aldrich company. Chitosan coating was prepared according to Vasilatos et al. (2013) method with some modifications (Vasilatos et al., 2013). Coatingforming solution of chitosan was prepared by dissolving $1.5 \mathrm{~g}$ chitosan powder in $100 \mathrm{~mL}$ of glacial acetic acid solution (1\% v/v) (as plasticizer) and was stirred $8 \mathrm{~h}$ at room temperature (final chitosan concentration was $1.5 \% \mathrm{w} / \mathrm{v}$ ) (Siripatrawan et al., 2012).

\subsection{Preparation of Cumin essential oil}

To prepare CEO, about $100 \mathrm{~g}$ of powdered cumin seed was placed in a blender containing $500 \mathrm{~mL}$ distilled water for $24 \mathrm{~h}$ and then was transferred to our hydro-distillation facility. The distillation was performed by Clevenger apparatus for $4 \mathrm{~h}$. The obtained EO dehydrated and dried using anhydrous $\mathrm{Na}_{2} \mathrm{SO}_{4}$, and then stored in dark glass bottles at $4^{\circ} \mathrm{C}$ for later use (Oroojalian, Kasra-Kermanshahi, Azizi, \& Bassami, 2010). Different concentrations of EO $(0.2,0.4$ and $0.6 \%(\mathrm{v} / \mathrm{w})$ were prepared by stock concentration. Tween $80(0.1 \% \mathrm{w} / \mathrm{v})$ was added to the solution as a surfactant to assist EO dissolution in coating forming solution (Peng et al., 2013). The solution stirred continually for 20 min at room temperature for better homogenization.

\subsection{Preparation of samples}

The chicken meat samples were coated with Ch and CEO solutions, singly or in combination. Samples of meat (ca.200 g) were immersed separately and were placed inside sterile packaging pouch, containing $100 \mathrm{~mL}$ of $\mathrm{Ch}$ solution $(1.5 \% \mathrm{w} / \mathrm{v})$ for $1.5 \mathrm{~min}$. After immersing, the excess solution was drained off on a sterilized rack (incubator) under aseptic conditions. Then, samples packaged into a clean sterile pouch. CEO in various concentration $(0.2,0.4$ and $0.6 \% \mathrm{w} / \mathrm{v})$ was added into the chicken meat samples $(0.25 \mathrm{~mL}$ of EO into 100 $\mathrm{g}$ of chicken meat) (Petrou et al., 2012; Vasilatos et al., 2013). Finally, the same above method was used for combine $\mathrm{Ch}$ and $\mathrm{CEO}$ for samples.

\subsection{Packaging of samples}

Chicken breast meat samples treated with coating solutions individually $(\sim 200 \mathrm{~g})$ and were transferred aseptically into the low-density polyethylene pouches. Treatments included the following groups: Blank or control (in the absence of $\mathrm{Ch}$ or CEO), Ch: (samples treated with Ch $1.5 \% \mathrm{w} / \mathrm{v}$ ), CEO: (samples treated with cumin oil $0.2,0.4$ and $0.6 \%$ ), Ch-CEO: (samples treated with combined $\mathrm{Ch} 1.5 \%$ and CEO 0.2, 0.4 and $0.6 \%$ ). All specimens were stored at the refrigerator temperature during the test period ( 9 days). 


\subsection{Microbiological analysis}

Chicken meat samples (25 g) were blended with $225 \mathrm{~mL}$ of sterile peptone water $(0.1 \%)$ (Merck, Darmstadt, Germany) in a stomacher bag and homogenised for $3 \mathrm{~min}$. The serial dilution method was applied for microbial test. For microbial analysis, $0.1 \mathrm{~mL}$ from serial dilutions of homogenized chicken meats were spread on the surface of agar plates. Total viable counts (TVCs) were determined in Plate Count agar medium (PCA, Merck, Darmstadt, Germany) by incubation for $48-72 \mathrm{~h}$ at $30^{\circ} \mathrm{C}$ (Giatrakou et al., 2010). Staphylococcus aureus count was determined in Baird-Parker agar medium (BPA, Merck, Darmstadt, Germany) by incubation for $48 \mathrm{~h}$ at $37^{\circ} \mathrm{C}$. To count moulds and yeasts, duplicate $0.1 \mathrm{~mL}$ of suitable dilutions were pour-plated on Sabouraud Dextrose agar medium (Merck, Darmstadt, Germany) and incubated at $25^{\circ} \mathrm{C}$ for 3-4 days (Siripatrawan et al., 2012). Enterobacteriaceae were determined by pour-overlay method using Violet Red Bile Glucose (VRBG) agar medium by incubation for $48 \mathrm{~h}$ at $37^{\circ} \mathrm{C}$ (Merck, Darmstadt, Germany) (Petrou et al., 2012; Vasilatos et al., 2013).

\subsection{Chemical and sensory characteristics 2.7.1. $\mathrm{pH}$}

The $\mathrm{pH}$ value determined by a $\mathrm{pH}$ meter (Kent EIL 7020). About $25 \mathrm{~g}$ of chicken meat sample was homogenised with $225 \mathrm{~mL}$ of distilled water and the homogenised samples were used for $\mathrm{pH}$ estimation (Petrou et al., 2012).

\subsubsection{DPPH assay}

DPPH test is the most commonly used method for measuring antioxidant capacity. 1 $\mathrm{mL}$ of the CEO in different concentration was added to $0.5 \mathrm{~mL}$ of a standard DPPH (SigmaAldrich) methanolic solution. The mixture was shaken and left standing in the dark at room temperature for $30 \mathrm{~min}$. The absorbance of the resulting solution was then measured at $517 \mathrm{~nm}$ (Mahdizadeh et al., 2020; Rebey et al., 2012). The Butylated hydroxytoluene (BHT) (Merck, Darmstadt, Germany) was used as standard and control sample. The capacity scavenging DPPH radical calculated by the following equation:
DPPH scavenging effect $(\%)=\left(\left(\mathrm{A}_{0}-\mathrm{A}_{1}\right) / \mathrm{A}_{0}\right) *$ 100

$\mathrm{A}_{0 \text { : }}$ absorbance of the control

$\mathrm{A}_{1}$ : absorbance of the sample

\subsubsection{Peroxide value}

Five $\mathrm{g}$ of meat samples and $30 \mathrm{~mL}$ of acid acetic and chloroform (Sigma-Aldrich) (ratio $3: 2$ ) were added to $0.5 \mathrm{~mL}$ Potassium iodide (KI) (Merck, Darmstadt, Germany) and was left for 1 min. Titration was performed with sodium thiosulfate $\left(\mathrm{Na}_{2} \mathrm{~S}_{2} \mathrm{O}_{3}\right)(0.1 \mathrm{~N})$ until yellow color appeared, and $0.5 \mathrm{~mL}$ of starch solution was added to appear purple color. Peroxide value (PV) is characterized as milliequivalents (meq) peroxide oxygen per $1 \mathrm{~kg}$ of lipids (Karakaya et al., 2011). The peroxide value calculated by the following equation:

$\mathrm{PV}\left(\frac{\mathrm{meq}}{\mathrm{kg}}\right)=\frac{(\mathrm{S}-\mathrm{B}) * \mathrm{~N} * 1000}{\mathrm{~W}}$

$\mathrm{S}$ : The volume of titrant $\left(\mathrm{Na}_{2} \mathrm{~S}_{2} \mathrm{O}_{3}\right.$ standard solution) consumed by sample $(\mathrm{mL})$

$\mathrm{B}$ : The volume of titrant $\left(\mathrm{Na}_{2} \mathrm{~S}_{2} \mathrm{O}_{3}\right.$ standard solution) consumed by control sample (mL)

$\mathrm{N}$ : Normality titrant $\left(\mathrm{Na}_{2} \mathrm{~S}_{2} \mathrm{O}_{3}\right)$

$\mathrm{W}$ : weight sample (fat extracted, g)

\subsubsection{TBARS assay}

The 2-thiobarbituric acid (TBA) assay commonly used to assess lipid oxidation and expressed as mg of malondialdehyde (MDA) per $\mathrm{kg}$ chicken meat samples (Xiong et al., 2015). Ten grams of the meat sample with $50 \mathrm{~mL}$ of distilled water were mixed in a $100 \mathrm{~mL}$ tall beaker, then were stirred by a glass bar for several seconds and left for approximately 30 min. The samples were homogenized at high speed as possible for $15 \mathrm{sec}$ by mixer. Then added $20 \mathrm{~mL}$ of $20 \%$ TBA and was placed for $10 \mathrm{~min}$ in ambient condition. Samples filtered through a Toyo filter paper No.42 with suction, and added distilled water until the solution level equals $100 \mathrm{~mL}$. Then, the absorbance of the obtained solution was measured at $532 \mathrm{~nm}$ by spectrophotometry (Ultrospec 2000, Scinteck, UK) (Alizadeh-Sani et al., 2020). TBA content was expressed as $\mu \mathrm{g}$ MDA per g chicken meat. The ability to lipid oxidation calculated by the following equation:

$\operatorname{MDA}(\mu \mathrm{g} / \mathrm{g})=\mathrm{E} 532 * 12.9$ 


\subsubsection{Total volatile nitrogen}

To determine total volatile nitrogen (TVN), the samples $(10 \mathrm{~g})$ were boiled for $25 \mathrm{~min}$ with Magnesium oxide ( $\mathrm{MgO})$ (2 g), the distilled water and Ammonia $\left(\mathrm{NH}_{3}\right)$ were taken up in $0.04 \mathrm{M}$ boric acid (Merck, Darmstadt, Germany) which was back titrated with $0.1 \mathrm{M}$ sulfuric acid $\left(\mathrm{H}_{2} \mathrm{SO}_{4}\right)$ (Merck, Darmstadt, Germany) with methyl red as indicator (Alizadeh-Sani et al., 2020). The control sample was without chicken meat. TVN value calculated by the following equation:

$\operatorname{TVN}\left(\frac{\mathrm{mg}}{100 \mathrm{~g}}\right.$ sample $)=v($ titrant $) * 14$

\subsection{Sensory analysis}

For the sensory evaluation of the samples, a semi-trained 7-person panel was used (laboratory - trained and postgraduate students). Panellists were asked to assess the odour, appearance, colour and overall acceptance of uncooked chicken meat samples during the storage period. Chicken meat samples were evaluated using a 0-9 ranging score from 9 (highest score) to 1 (lowest score) (Petrou et al., 2012).

\subsection{Statistical analysis}

The statistical analysis was performed using $\mathrm{R}$ software. Data were subjected to analysis of nonparametric Kruskal-Wallis one-way analysis of variance. P-values less than 0.05 were considered statistically significant. All tests of this study were performed in triplicate. Results are reported as mean values \pm standard deviation (S.D)

\section{Results and Discussion}

Seven type samples of $\mathrm{Ch}$ and CEO $(0.2,0.4$ and $0.6 \%(\mathrm{w} / \mathrm{v}))$ alone or in combination (Ch-CEO at $0.2,0.4$ and $0.6 \%(\mathrm{w} / \mathrm{v}))$ were prepared and microbial and physiochemical tests were examined.

\subsection{Microbiological analysis}

All of microbiological results were shown in Figures 1 to 5 .

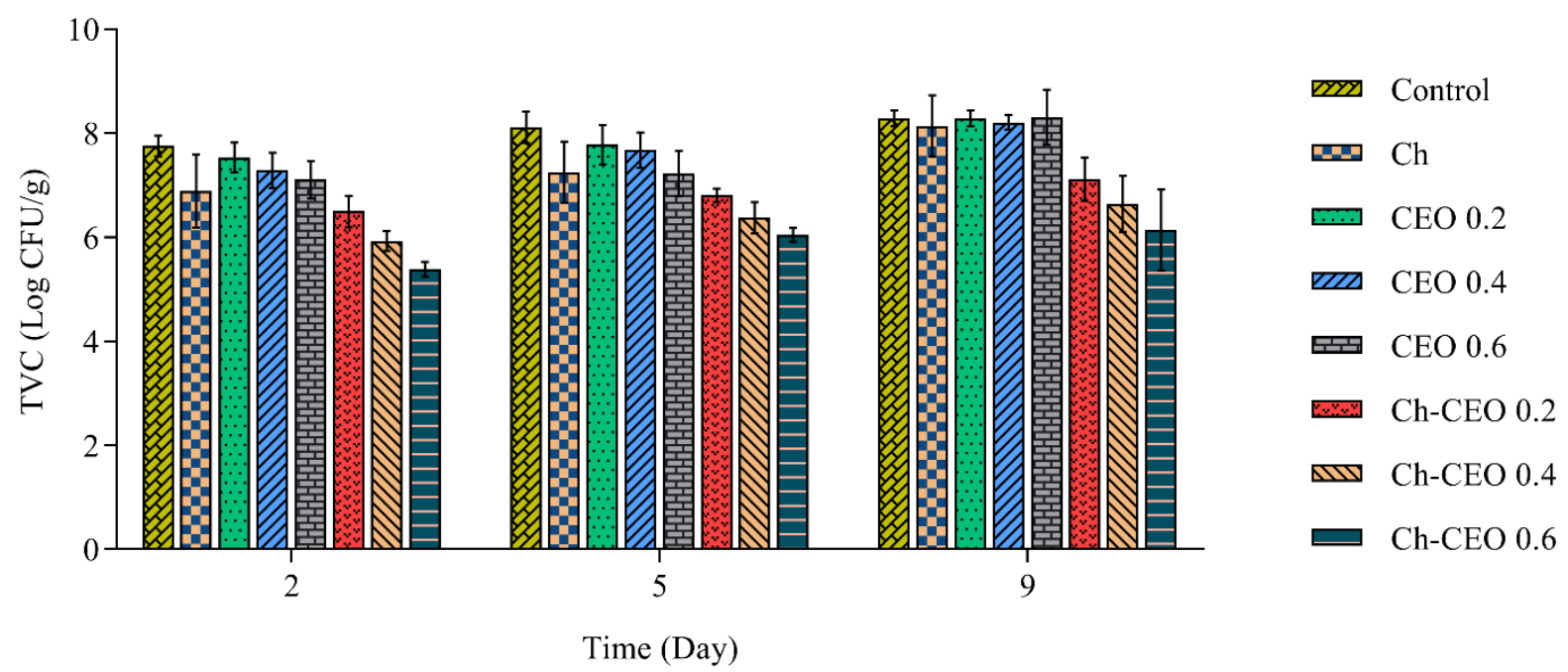

Figure 1. Effect of edible biodegradable coating containing Chitosan and CEO on the total viable counts (TVC) of chicken meat during refrigerated storage.

\subsubsection{Total viable count}

On the second day, the initial total count was assessed and result was shown $7.8 \log \mathrm{cfu} / \mathrm{g}$, increasing the final population during storage up (9 days) to reached ca. $8.3 \mathrm{log} \mathrm{cfu} / \mathrm{g}$ (Chitosan samples) (Figure 1). These results indicated that 
counts for treatments were about $0.5-1.3 \log$ $\mathrm{cfu} / \mathrm{g}$ lower than in the control samples. Data analysis was released a significant difference ( $p$ $<0.05$ ) for TVC between control samples and wrapped Ch-CEO 0.2, Ch-CEO 0.4 and ChCEO $0.6 \%$. TVC values of chicken meat samples exceed of $8.5 \mathrm{log} \mathrm{cfu} / \mathrm{g}$, which was considered as the upper acceptability limit for fresh meat on days $9^{\text {th }}$ in control, Ch, CEO 0.2, 0.4 and $0.6 \%$ treatments. While samples treated with Ch-CEO 0.4 and Ch-CEO 0.6 never reached the limit value after 7 days. Thus, in comparison with control samples, an increase in microbiological shelf life of $9^{\text {th }}$ was achieved for Ch-CEO 0.4 and Ch-CEO 0.6 samples. This shelf life extension of these two groups could be due to the antimicrobial action CEO components (especially, cuminic alcohol) and of $\mathrm{Ch}$, which increases antimicrobial activity (Allahghadri et al., 2010).

Recently, in a related study, a $9^{\text {th }}$ microbiological shelf life increment was obtained for a fresh chicken breast meat treated with modified atmosphere $\left(70 / 30 \mathrm{CO}_{2} / \mathrm{N}_{2}\right)$ and oregano oil (0.1\%) (Chouliara et al., 2007). In other studies, Giatrakou et al. (2010) indicated that microbiological shelf life for a ready-to-eat chicken pepper kebab treated by either thyme oil $(0.2 \% \mathrm{v} / \mathrm{w})$ or chitosan $(1.5 \% \mathrm{w} / \mathrm{v})$ increased after 5 days (Giatrakou et al., 2010). Siripatrawan et al. (2012) reported a reduction of microbial counts by an average of $2.52 \mathrm{log}$ $\mathrm{cfu} / \mathrm{g}$ for pork sausages treated by chitosan incorporating green tea extract $(20 \% \mathrm{w} / \mathrm{v})$ on day $20^{\text {th }}$ (Siripatrawan et al., 2012). Petrou et al. (2012) reported a shelf life extension of 5-6 days for a chicken breast meat treated with chitosan $1.5 \%(\mathrm{w} / \mathrm{v})$ or oregano oil $0.25 \%(\mathrm{v} / \mathrm{w})$ and modified atmosphere packaging than control samples (Petrou et al., 2012). Also, the combined use of chitosan and rosemary oil on the preservation of turkey meat led to a reduction of TVC by $1.0 \log \mathrm{cfu} / \mathrm{g}$, extending their shelf life at $2^{\circ} \mathrm{C}$ (Vasilatos et al., 2013).

Similar to previous studies in present study, among all the treatments, Ch-CEO 0.6 and ChCEO 0.4 were the most effective on the growth inhibition of TVC (Figure 1a) in the storage period. Different antimicrobial effects were detected when using an edible coating based on chitosan combined with $0.2,0.4$ and $0.6 \%(\mathrm{v} / \mathrm{w})$ of CEO against various microbial groups in fresh chicken meat stored at $4^{\circ} \mathrm{C}$. Ch prevents growth and spore germination bacteria due to the absorption of minerals and in particular calcium (Plascencia-Jatomea et al., 2003). The use of Ch has been proven to be a very effective way to control the microbial growth rate on chicken meat than the use of the direct addition of CEO.

\subsubsection{Enterobacteriaceae count}

In our study, Enterobacteriaceae (Coliforms), the most important part of the microbial flora of chicken meat with a psychotropic facultative anaerobic bacterial group and final counts reached to ca $8.4 \mathrm{log}$ $\mathrm{cfu} / \mathrm{g}$ on after 9 days (Figure 2). As previously noted, Ch-CEO 0.2, 0.4 and $0.6 \%$ treatments caused a significant reduction in coliform counts (approximately 1.5-2.2 log cycles) compared to control samples on day $9^{\text {th }}(\mathrm{p}<0.05)$. Petrou et al. (2012) reported that a decrease of microbial counts by an average of 3-4 log cfu/g for chicken breast meat treated with chitosan/oregano oil and modified atmosphere than control samples on day $12^{\text {th }}$ (Petrou et al., 2012). Giatrakou et al. (2010) showed that Enterobacteriaceae growth in ready to cook chicken product were inhibited by use of chitosan $1.5 \% \mathrm{w} / \mathrm{v}$ and thyme oil 0.2 w/v under aerobic packaging (Giatrakou et al., 2010). Chantarasataporn et al. (2014) showed that the total Enterobacteriaceae in minced pork control samples significant increase of 5 to $6 \mathrm{log}$ $\mathrm{cfu} / \mathrm{g}$ during storage while samples containing oligochitosan 0.2 and $0.4 \%$ reduced about 1 and $2 \log \mathrm{cfu} / \mathrm{g}$ (Chantarasataporn et al., 2014). 


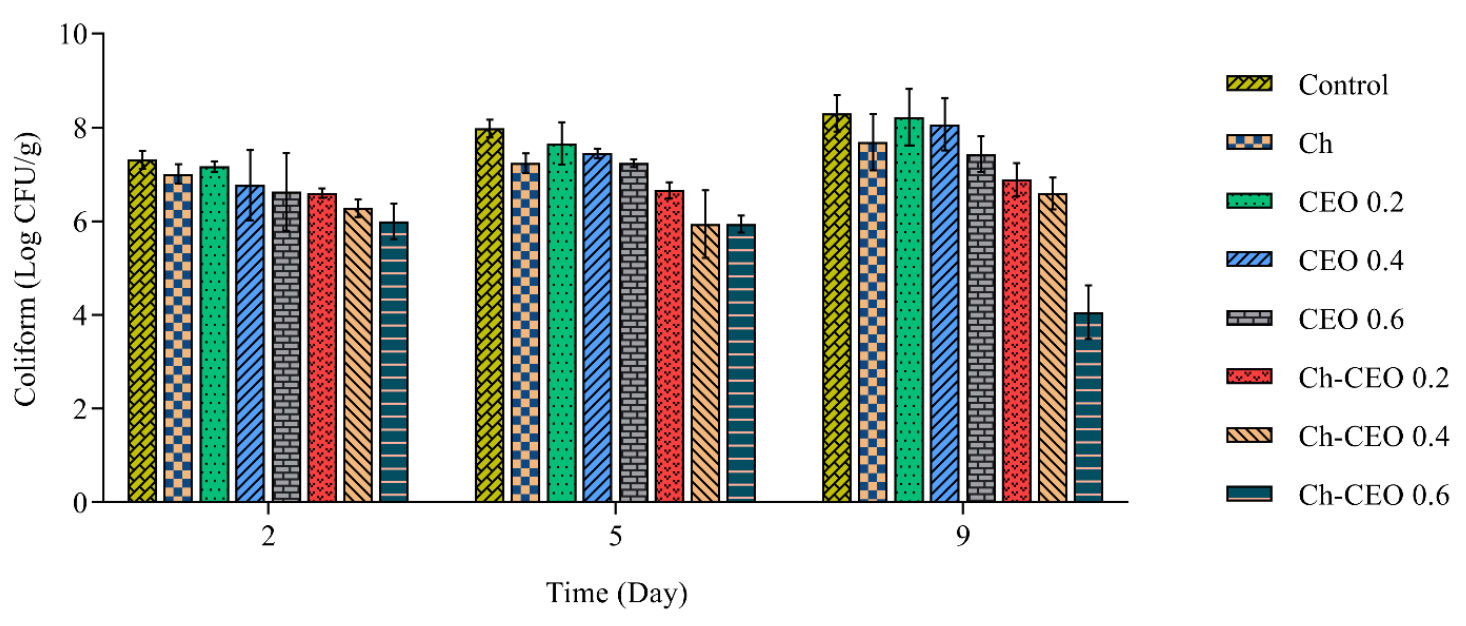

Figure 2. Effect of edible biodegradable coating containing Chitosan and CEO on the Coliforms of chicken meat during refrigerated storage.

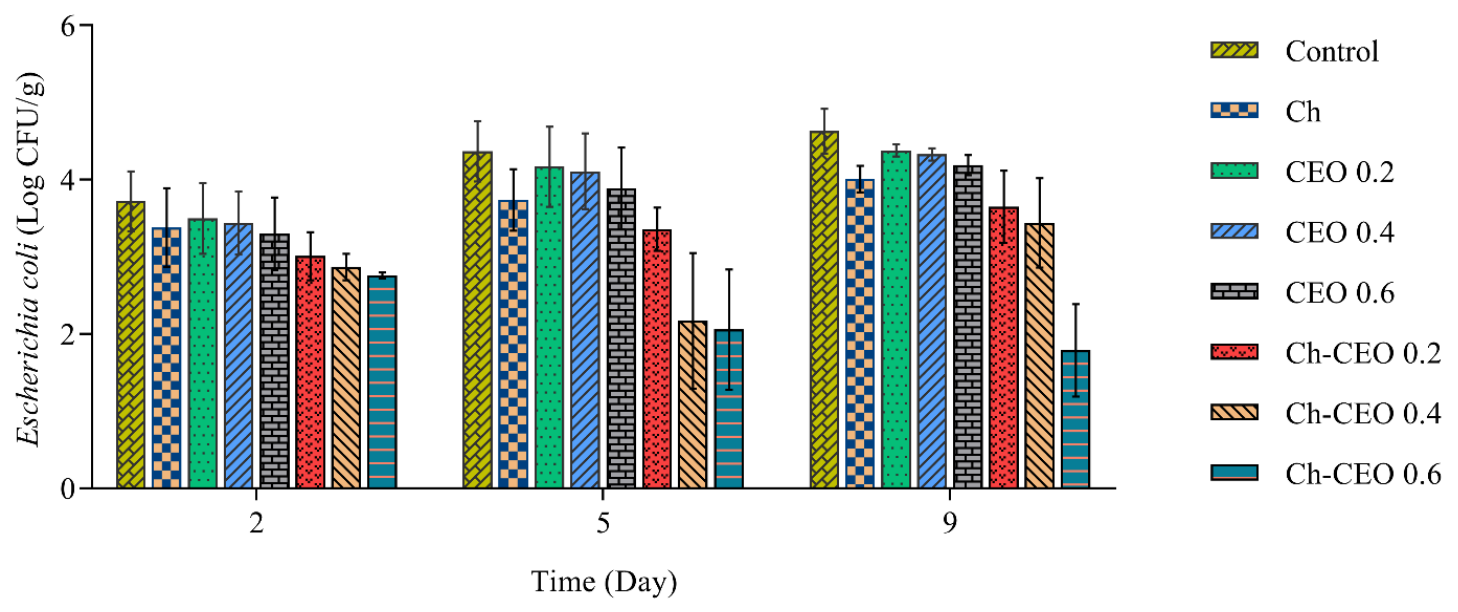

Figure 3. Effect of edible biodegradable coating containing Chitosan and CEO on the E. coli of chicken meat during refrigerated storage

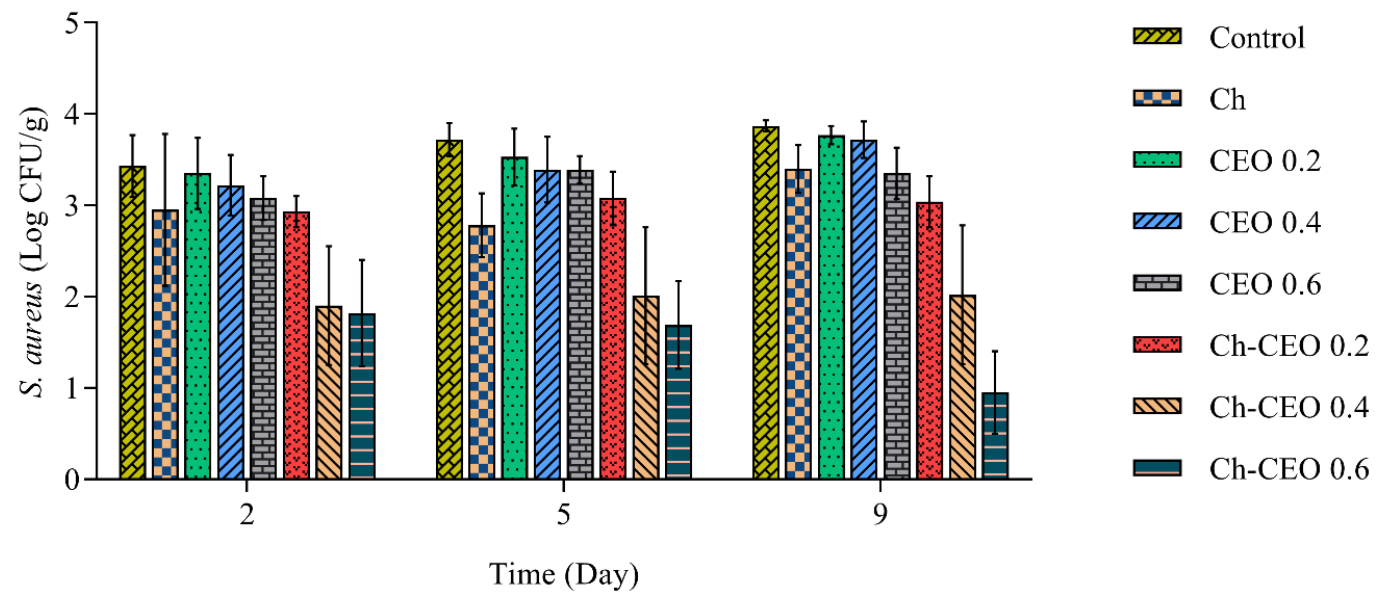

Figure 4. Effect of edible biodegradable coating containing Chitosan and CEO on the S. aureus of chicken meat during refrigerated storage. 


\subsubsection{Escherichia coli count}

The initial population of E.coli was ca. 3.8 $\log \mathrm{cfu} / \mathrm{g}$ and increased to $4.7 \mathrm{log} \mathrm{cfu} / \mathrm{g}$ at the end of the storage period (day $9^{\text {th }}$ ) (Figure 3 ).

Although, lower E.coli counts $(\mathrm{p}<0.05)$ were recorded for Ch-CEO $0.6 \%$ samples stored at $4{ }^{\circ} \mathrm{C}$. Of all the antimicrobial treatments in our study, Ch-CEO $0.6 \%$ and Ch-CEO $0.4 \%$ groups demonstrated to be the greatest effect inhibitory of growth of E.coli in samples, approximately resulting in a $2.1 \log$ cycle decrease during the storage period.

These antimicrobial effects are usually attributed to the effective compounds in the $\mathrm{CEO}$ and the antimicrobial properties of $\mathrm{Ch}$. Allahghadri et al. (2010) demonstrated that CEO dilutions had strong antimicrobial effects against the E. coli and E. coli was the most sensitive

\subsubsection{Staphylococcus aureus count}

S. aureus count in second day was $3.5 \mathrm{log}$ $\mathrm{cfu} / \mathrm{g}$, increased during storage and reached final population ca. $3.9 \mathrm{log} \mathrm{cfu} / \mathrm{g}$ for control sample (Figure 4). In contrast, counts related for ChCEO $0.4 \%$ and Ch-CEO $0.6 \%$ were about $0.7-$ $1.2 \mathrm{log} \mathrm{cfu} / \mathrm{g}$ lower than the control samples. S.aureus population was significantly $(\mathrm{p}<0.05)$ lower in Ch-CEO 0.6\% samples compared to all the other treatments. The direct addition of CEO without the use of a chitosan, in general, did not improve the microbial quality chicken meat samples. S.aureus count was not significantly difference $(p>0.05)$ for CEO 0.2\%, CEO 0.4\% and CEO $0.6 \%$ samples compared to the control samples. García-Díez et al. (2017) indicated that CEO inhibited the growth of $S$. aureus associated to dry-cured meat products (GarcíaDíez et al., 2017). Also, Sadegi et al. (2012) showed that the use of cumin essential oil significantly inhibited the growth of $S$. aureus bacteria in Iranian white brined cheese (Sadeghi et al., 2013). In another study that investigated the effects of electro-spun chitosan-based nanofibers, it was shown that chitosan significantly inhibited the growth of $S$. aureus in meat samples (Arkoun et al., 2017). bacteria to the $\mathrm{CEO}$ with the lowest $\mathrm{MBC}$ value $(1 \mu \mathrm{L} / \mathrm{mL})$ (Allahghadri et al., 2010).

In another study, García-Díez et al. (2016) indicated that CEO inhibited the growth of $E$. coli related to dry-cured meat products (GarcíaDíez et al., 2017). In addition, accordant with the results of this study, Shekarforoush et al. (2015) showed that using chitosan and oregano CEO in combination are more effective in reducing the number of spoilage and pathogenic bacteria such as E. coli O157:H7 in cured chicken meat (Shekarforoush et al., 2015).

Arkoun et al. (2017) also, proved that electro-spun chitosan-based nanofibers reduced the growth of spoilage and pathogenic bacteria, including $E$. coli, and resulted in an increase in the shelf life of the meat samples for one week (Arkoun et al., 2017)

\section{1. 5. Moulds and yeasts}

Eventually, with regard to moulds and yeasts known species to be involved at the spoilage of poultry meat (Petrou et al., 2012). The antimicrobial treatments $\mathrm{Ch}-\mathrm{CEO} 0.2 \%$, ChCEO $0.4 \%$ and $\mathrm{Ch}-\mathrm{CEO} \quad 0.6 \%$ led to a significant reduction $(p<0.05)$ in yeasts and moulds count compared to the control group up to day $9^{\text {th }}$ of storage (Figure 5). On the other hand, moulds and yeasts populations were significantly lower for Ch-CEO $0.6 \%$ samples compared to the wrapped chitosan samples during the storage $(p<0.05)$. Thus, while the Ch-CEO $0.6 \%$ showed effectiveness on the moulds and yeasts after 9 days, but the same result was shown in CEO $0.6 \%$ treatment without chitosan coating while did not show this parameter in microbial counts. In other studies, involving preservation of chicken breast meat treatments with chitosan or oregano oil (Petrou et al., 2012) led to a reduction two cycles in compared with control samples. Also, Giatrakou et al. (2010) reported the effects of chitosan and thymol oil beside aerobic packaging that led to count remained below $4.0 \mathrm{log} \mathrm{cfu} / \mathrm{g}$ during the entire storage period than the control samples (Giatrakou et al., 2010). In another study, similarly, Siripatrawa et al. (2012) indicated that chitosan incorporation with green tea extract 
caused shelf life extension of pork sausages 3 and $2 \log$ cycles, respectively, compared to control samples and chitosan wrapped samples (Siripatrawan et al., 2012).

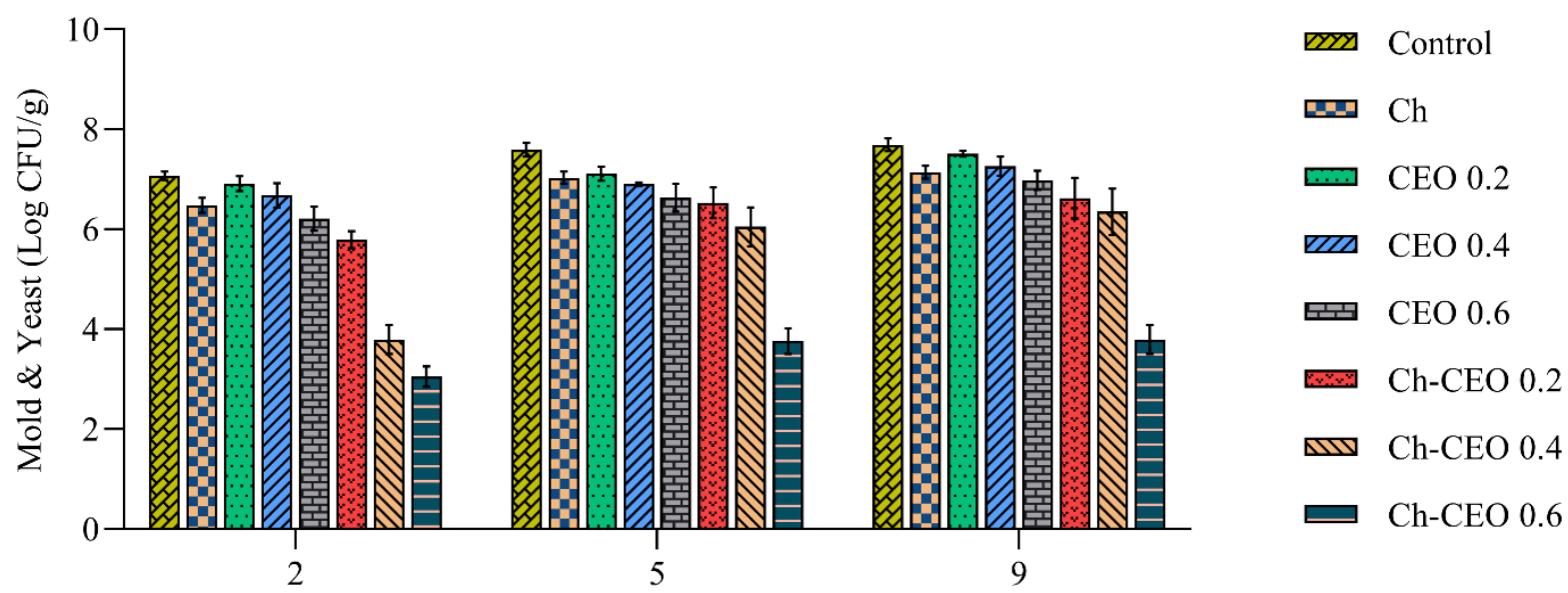

Time (Day)

Figure 5. Effect of edible biodegradable coating containing Chitosan and CEO on the mold and yeast of chicken meat during refrigerated storage.

\subsection{Physicochemical changes}

\subsection{1. pH value}

The $\mathrm{pH}$ value of control and treated chicken meat samples during storage at $4^{\circ} \mathrm{C}$ are shown in Table 1 . The primary $\mathrm{pH}$ of the chicken meat samples was 6.1, whereas at the end of storage final $\mathrm{pH}$ was 7.5 at control samples. The $\mathrm{pH}$ value of treated chicken meat samples decreased during 9 days; although, between control and CEO groups, no significant difference was observed $(\mathrm{p}>0.05)$ in this time. Treatments containing Ch-CEO 0.2, 0.4 and $0.6 \%$ resulted in lower $\mathrm{pH}$ value $(\mathrm{p}<0.05)$ compared to the other groups.
Our results seem to be in agreement with those reported by Giatrakou et al. (2010) for reduced ready to cook chicken product containing chitosan (Giatrakou et al., 2010). Whereas, Petrou et al. (2012) reported no significant difference between chitosan, thymol oil and the combination of chitosan and thymol oil for chicken breast meat (Petrou et al., 2012). Also, Soultos et al. (2008) reported no significant difference in $\mathrm{pH}$ value between pork sausages samples treated with chitosan and nitrite, separately or in combination (Soultos et al., 2008).

Table 1. Effect of edible biodegradable coating containing Chitosan and EO on the chemical properties of chicken meat during refrigerated storage

\begin{tabular}{|c|l|c|c|c|c|}
\hline Days & \multicolumn{1}{|c|}{ Groups } & $\mathrm{pH}$ & PV $(\%)$ & TBARS $(\mu \mathrm{g}$ MDA/g) & TVN $(\mathrm{mg} / 100 \mathrm{~g})$ \\
\hline \multirow{5}{*}{2} & Control & $6.1 \pm 0.264^{\mathrm{a}}$ & $1.9 \pm 0.115^{\mathrm{a}}$ & $0.006 \pm 0.001^{\mathrm{a}}$ & $13 \pm 8.08^{\mathrm{a}}$ \\
\cline { 2 - 6 } & Ch & $5.6 \pm 0.251^{\mathrm{bcd}}$ & $1.5 \pm 0.115^{\mathrm{b}}$ & $0.005 \pm 0.0005^{\mathrm{a}}$ & $7.7 \pm 3.89^{\mathrm{ab}}$ \\
\cline { 2 - 6 } & CEO 0.2\% & $5.8 \pm 0.152^{\mathrm{ac}}$ & $1.3 \pm 0.230^{\mathrm{b}}$ & $0.003 \pm 0.004^{\mathrm{ab}}$ & $9.8 \pm 3.70^{\mathrm{ab}}$ \\
\cline { 2 - 6 } & CEO 0.4\% & $5.7 \pm 0.152^{\mathrm{bc}}$ & $0.9 \pm 0.115^{\mathrm{ce}}$ & $0.002 \pm 0.0006^{\mathrm{bc}}$ & $9.1 \pm 1.85^{\mathrm{ab}}$ \\
\cline { 2 - 6 } & CEO 0.6\% & $5.6 \pm 0.152^{\mathrm{bcd}}$ & $0.4 \pm 0.1^{\mathrm{d}}$ & $0.0004 \pm 0.0004^{\mathrm{c}}$ & $6.3 \pm 1.32^{\mathrm{b}}$ \\
\cline { 2 - 6 } & Ch-CEO 0.2\% & $5.4 \pm 0.057^{\mathrm{bde}}$ & $1.1 \pm 0.1^{\mathrm{c}}$ & $0.004 \pm 0.0005^{\mathrm{ad}}$ & $8.1 \pm 2.65^{\mathrm{a}}$ \\
\cline { 2 - 6 } & Ch-CEO 0.4\% & $5.3 \pm 0.057^{\mathrm{de}}$ & $0.8 \pm 0.05^{\mathrm{e}}$ & $0.004 \pm 0.001^{\mathrm{ad}}$ & $6.9 \pm 1.40^{\mathrm{a}}$ \\
\cline { 2 - 6 } & Ch-CEO 0.6\% & $5.2 \pm 0.057^{\mathrm{e}}$ & $0.4 \pm 0.11^{\mathrm{d}}$ & $0.0026 \pm 0.0005^{\mathrm{bcd}}$ & $5.6 \pm 1.27^{\mathrm{b}}$ \\
\hline \multirow{3}{*}{5} & Control & $6.7 \pm 0.251^{\mathrm{a}}$ & $3.13 \pm 0.230^{\mathrm{a}}$ & $0.010 \pm 0.001^{\mathrm{a}}$ & $28 \pm 0.00^{\mathrm{a}}$ \\
\cline { 2 - 6 } & Ch & $5.5 \pm 0.076^{\mathrm{b}}$ & $1.8 \pm 0.115^{\mathrm{b}}$ & $0.006 \pm 0.004^{\mathrm{b}}$ & $6.5 \pm 2.13^{\mathrm{bc}}$ \\
\cline { 2 - 6 } & CEO 0.2\% & $6.6 \pm 0.251^{\mathrm{a}}$ & $1.2 \pm 0.2^{\mathrm{c}}$ & $0.001 \pm 0.00^{\mathrm{cd}}$ & $14.6 \pm 5.12^{\mathrm{d}}$ \\
\hline
\end{tabular}


Shahvandari et al./ Carpathian Journal of Food Science and Technology, 2021, 13(1), 75-89

\begin{tabular}{|c|c|c|c|c|c|}
\hline & CEO $0.4 \%$ & $6.4 \pm 0.251^{\mathrm{a}}$ & $1 \pm 0.1^{\mathrm{c}}$ & $0.0007 \pm 0.0001^{\mathrm{c}}$ & $15.8 \pm 2.91^{\mathrm{d}}$ \\
\hline & CEO $0.6 \%$ & $5.3 \pm 0.115^{b}$ & $0.6 \pm 0.2^{\mathrm{d}}$ & $0.0004 \pm 0.0001^{\mathrm{c}}$ & $10 \pm 1.06^{\mathrm{b}}$ \\
\hline & Ch-CEO $0.2 \%$ & $5.6 \pm 0.180^{\mathrm{b}}$ & $1.2 \pm 0.2^{\mathrm{c}}$ & $0.006 \pm 0.001^{\mathrm{b}}$ & $8.1 \pm 1.02^{b c}$ \\
\hline & Ch-CEO $0.4 \%$ & $5.4 \pm 0.152^{b}$ & $0.9 \pm 0.05^{\mathrm{ce}}$ & $0.005 \pm 0.001^{\mathrm{b}}$ & $7.3 \pm 1.49^{\mathrm{bc}}$ \\
\hline & Ch-CEO 0.6\% & $5.3 \pm 0.115^{b}$ & $0.7 \pm 0.1^{\mathrm{de}}$ & $0.004 \pm 0.001^{\mathrm{bd}}$ & $5.4 \pm 2.27^{\mathrm{c}}$ \\
\hline \multirow{8}{*}{9} & Control & $7.5 \pm 0.152^{\mathrm{a}}$ & $4.6 \pm 0.577^{\mathrm{a}}$ & $0.02 \pm 0.00^{\mathrm{a}}$ & $48.5 \pm 0.80^{\mathrm{a}}$ \\
\hline & $\mathrm{Ch}$ & $5.9 \pm 0.229^{\mathrm{bd}}$ & $2.5 \pm 0.503^{b}$ & $0.01 \pm 0.005^{\mathrm{b}}$ & $9.8 \pm 1.4^{\mathrm{b}}$ \\
\hline & CEO $0.2 \%$ & $7.2 \pm 0.152^{\mathrm{ac}}$ & $1.5 \pm 0.1^{\mathrm{c}}$ & $0.002 \pm 0.001^{\mathrm{cd}}$ & $35.4 \pm 14.02^{\mathrm{ac}}$ \\
\hline & CEO $0.4 \%$ & $7.1 \pm 0.115^{\mathrm{c}}$ & $1.2 \pm 0.1^{\mathrm{cd}}$ & $0.001 \pm 0.0008^{\mathrm{cd}}$ & $33.3 \pm 14.09^{c}$ \\
\hline & CEO $0.6 \%$ & $7.0 \pm 0.115^{c}$ & $0.9 \pm 0.057^{\mathrm{d}}$ & $0.0008 \pm 0.001^{\mathrm{c}}$ & $26.6 \pm 9.18^{c}$ \\
\hline & Ch-CEO $0.2 \%$ & $6.1 \pm 0.346^{\mathrm{b}}$ & $1.6 \pm 0.152^{\mathrm{c}}$ & $0.01 \pm 0.00^{\text {be }}$ & $12.8 \pm 0.40^{\mathrm{b}}$ \\
\hline & Ch-CEO 0.4\% & $5.7 \pm 0.115^{\mathrm{d}}$ & $1.3 \pm 0.1^{\mathrm{cd}}$ & $0.007 \pm 0.006^{\mathrm{de}}$ & $7 \pm 1.4^{\mathrm{b}}$ \\
\hline & Ch-CEO 0.6\% & $5.6 \pm 0.152^{d}$ & $0.9 \pm 0.152^{\mathrm{d}}$ & $0.006 \pm 0.004^{\mathrm{ce}}$ & $4.8 \pm 1.4^{b}$ \\
\hline
\end{tabular}

Any two means in the same column followed by the same letter are not significantly $(\mathrm{p}>0.05)$ different from Duncan's multiple range tests. Ch: Chitosan, EO: Essential oil, CEO: Cumin essential oil, pH, peroxide value (PV), Malondialdehyde (MDA), Total volatile nitrogen (TVN), Thiobarbituric acid (TBARS).

\subsubsection{DDPH assay}

Antioxidant properties, especially radical scavenging activity, it's too important due to the deleterious role of free radicals in food and biological system (Wang et al., 2015). Figure 6 shows DPPH free radical scavenging activity of CEO with different concentrations compared to BHT (synthetic antioxidant). In the present study was observed statistically significant difference $(\mathrm{p}<0.05)$ between BHT and CEO $0.2,0.4$ and $0.6 \%$. The variety EO showed high antioxidant activities. Solvent nature had significant effect on DPPH scavenging activity of CEO. Rebey et al. (2012) reported highest antioxidant activities water extract cumin (Rebey et al., 2012). Also, Martins et al. (2012) stated chitosan film in combination $\alpha$-tocopherol with concentration 0.1 and $0.2 \%$ the highest DPPH scavenging activity, whereas no significant difference between two $\alpha$-tocopherol concentration (Martins et al., 2012).

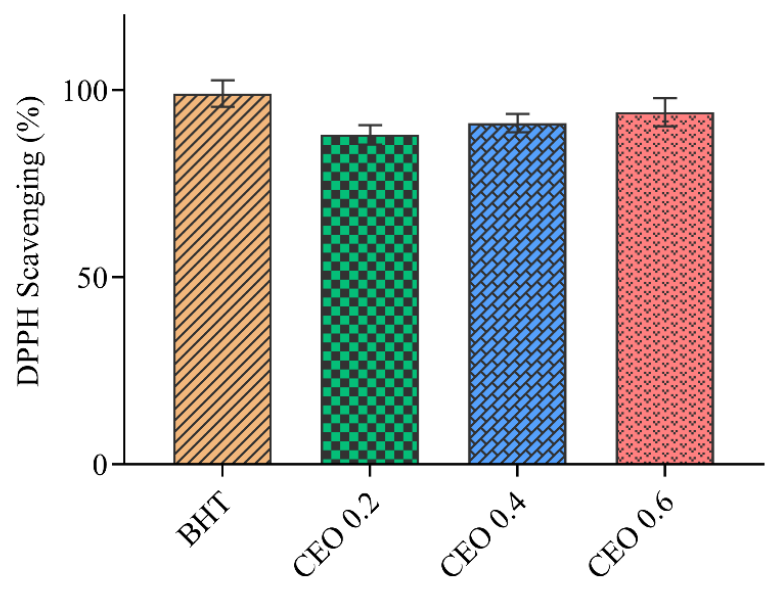

Figure 6. Antioxidant activities of Chitosan and CEO. BHT was used as standard samples. Each point represents the mean $\pm \mathrm{SD}$. 


\subsubsection{Thiobarbituric acid value}

The lipid oxidation changes (TBA value) in control and treatment chicken meat samples are shown in Table1. At during storage, results were released significantly higher $(p<0.05)$ TBA in control samples than those wrapped with EO $0.2,0.4$ and $0.6 \%$, respectively. Therefore, combination of CEO and chitosan coating increased the antioxidant properties of the coating. The TBA values of Ch-CEO $0.6 \%$ wrapped samples were lower than those wrapped with chitosan coating, whereas not showing statistically difference significantly $(\mathrm{p}$ $>0.05)$.

Similarly, Siripatrawan et al. (2012) showed that the antioxidant activities of $\mathrm{Ch}$ film with incorporation green tea extract increased in pork sausages (Siripatrawa et al., 2012). Furthermore, Ch with oregano oil and modified atmosphere packaging was shown to the lowest TBA values in 12 days of storage in chicken breast meat (Petrou et al., 2012). Soultos et al. (2008) shows low levels of lipid oxidation in sausage samples treated with chitosan concentration 0.5 and $1 \%$ in combination nitrite $150 \mathrm{ppm}$ (Soultos et al., 2008).

\subsubsection{Peroxide value}

Concentration of elementary oxidation products in the lipid breakdown of the chicken meat sample measured as PV after 9 days storage at $4{ }^{\circ} \mathrm{C}$ are presented in Table 1. Samples containing chitosan and combination (CEO 0.2, 0.4 and $0.6 \%$ ) together with those containing only CEO exhibited the lowest $(p<0.05)$ values for PV compared to the control samples. The best anti-oxidative effect $(\mathrm{p}<0.05)$ was obtained by the combination of $\mathrm{Ch}$ and CEO $0.6 \%$ for the PV values that had lower at the end of storage period.

In this study, was not seen statistically difference significantly between control samples with combination of $\mathrm{Ch}$ and $\mathrm{CEO} 0.2$ or samples containing only CEO $0.2 \%(\mathrm{p}>0.05)$.

Georgantelis et al. (2007) observed a decrease in the peroxide value of pork sausage samples containing $\mathrm{Ch}$ with rosemary EO, $\alpha$ - tocopherol and samples containing only $\mathrm{Ch}$ compared $\alpha$ - tocopherol and control samples (Georgantelis et al., 2007).

\subsubsection{Total volatile nitrogen value}

Changes in total volatile nitrogen value (TVN) content during the storage time are shown in Table 1. The primary TVN value was about $13 \mathrm{mg} / 100 \mathrm{~g}$ in second day, and then it increased with time of refrigerator storage for the control samples on day $9^{\text {th }}$. The control samples had the highest TVN values, while the treatment sample Ch-CEO 0.4 and $0.6 \%$ had lowered values $(p<0.05)$. In the current study was not observed statistically difference significantly between control samples with combination of $\mathrm{Ch}$ and $\mathrm{CEO} 0.4,0.6 \%$ and samples containing only CEO $0.2,0.4 \%$ with combination $\mathrm{Ch}$ and $\mathrm{CEO} 0.6(\mathrm{p} \geq 0.05)$.

Fan et al. (2009) reported that TVN contents increased from an initial value to $18.8 \mathrm{mg} / 100 \mathrm{~g}$ in fish samples were given a dip treatment in $2 \%$ chitosan solution than to $30.2 \mathrm{mg} / 100 \mathrm{~g}$ in control samples (Fan et al., 2009). The study conducted by Chantarasataporn et al. (2014) showed the amount of biogenic amines in minced pork samples of treated oligo-chitosan in the first day was about $50 \mathrm{mg} / \mathrm{kg}$ by increasing the concentration of oligo-chitosan to 0.2 and 0.4 the amount of biogenic amines reached the acceptable level on the second day (under 50 $\mathrm{mg} / \mathrm{kg}$ ) (Chantarasataporn et al., 2014).

\subsubsection{Sensory analysis}

Means of sensory analysis scores including odour, colour and overall acceptance of control chicken meat sample and those wrapped with $\mathrm{Ch}$ coating, treated (CEO 0.2, 0.4 and $0.6 \%$ ) and treated (Ch-CEO $0.2 \%$, Ch-CEO 0.4\%, Ch-CEO $0.6 \%$ ) during storage at $4{ }^{\circ} \mathrm{C}$ are shown in Table 2. The sensory analysis results showed significant differences $(p<0.05)$ for odour between control samples with treated samples (Ch-CEO 0.2, 0.4, and 0.6\%), and colour was shown between control samples with treated samples (Ch-CEO 0.4 and $0.6 \%$ ) and overall acceptance. Results showed significant differences $(p<0.05)$ for overall acceptance between control samples with treated samples that were Ch-CEO 0.4 and $0.6 \%$. 
In this study the existence of chitosan $(1.5 \%$ $\mathrm{w} / \mathrm{v}$ ) in Ch-CEO $0.2,0.4$ and $0.6 \%$ treated samples a very desirable odour and appearance color in the chicken meat, increasing the natural freshness of the chicken meat, while addition of cumin oil $(0.2,0.4$ and $0.6 \%)$ in chicken meat samples caused to off odour and slime. According to Giatrakou et al. (2010) study, the addition of chitosan with thyme oil to cook chicken product gave a more acceptable taste and odour as compared to the untreated samples (Giatrakou et al., 2010).

Table 2. Effect of edible biodegradable coating containing Chitosan and CEO on the sensory analysis of chicken meat during refrigerated storage

\begin{tabular}{|c|c|c|c|c|}
\hline \multicolumn{5}{|c|}{ Sensorial indexes } \\
\hline Days & Groups & Colour & Odour & Acceptability \\
\hline \multirow[t]{8}{*}{2} & Control & $7.8^{\mathrm{a}}$ & $7.2^{\mathrm{b}}$ & $8.0^{\mathrm{a}}$ \\
\hline & $\mathrm{Ch}$ & $7.8^{\mathrm{a}}$ & $8.0^{\mathrm{b}}$ & $8.2^{\mathrm{a}}$ \\
\hline & CEO $0.2 \%$ & $7.8^{\mathrm{a}}$ & $7.8^{\mathrm{b}}$ & $7.8^{\mathrm{a}}$ \\
\hline & CEO $0.4 \%$ & $7.1^{\mathrm{a}}$ & $7.1^{\mathrm{b}}$ & $7.5^{\mathrm{a}}$ \\
\hline & CEO $0.6 \%$ & $7.0^{\mathrm{a}}$ & $6.8^{\mathrm{c}}$ & $6.5^{\mathrm{b}}$ \\
\hline & Ch-CEO $0.2 \%$ & $8.2^{\mathrm{a}}$ & $8.1^{\mathrm{b}}$ & $8.4^{\mathrm{a}}$ \\
\hline & Ch-CEO $0.4 \%$ & $8.2^{\mathrm{a}}$ & $8.2^{\mathrm{b}}$ & $8.5^{\mathrm{a}}$ \\
\hline & Ch-CEO $0.6 \%$ & $8.2^{\mathrm{a}}$ & $8.5^{\mathrm{b}}$ & $9.0^{\mathrm{a}}$ \\
\hline \multirow[t]{8}{*}{5} & Control & $3.5^{\mathrm{ab}}$ & $1.4^{\mathrm{e}}$ & $4.1^{\mathrm{a}}$ \\
\hline & $\mathrm{Ch}$ & $7.5^{\mathrm{d}}$ & $8.1^{\mathrm{f}}$ & $7.4^{\mathrm{b}}$ \\
\hline & CEO $0.2 \%$ & $4.5^{\mathrm{ab}}$ & $2.4^{\mathrm{e}}$ & $2.4^{\mathrm{a}}$ \\
\hline & CEO $0.4 \%$ & $3.5^{\mathrm{ab}}$ & $2.0^{\mathrm{e}}$ & $1.8^{\mathrm{a}}$ \\
\hline & CEO $0.6 \%$ & $2.0^{\mathrm{ab}}$ & $1.5^{\mathrm{e}}$ & $1.7^{\mathrm{a}}$ \\
\hline & Ch-CEO $0.2 \%$ & $7.8^{\mathrm{d}}$ & $7.7^{\mathrm{f}}$ & $7.5^{\mathrm{b}}$ \\
\hline & Ch-CEO 0.4\% & $8.4^{\mathrm{d}}$ & $8.0^{\mathrm{f}}$ & $8.0^{\mathrm{b}}$ \\
\hline & Ch-CEO 0.6\% & $8.4^{\mathrm{d}}$ & $8.2^{\mathrm{f}}$ & $8.5^{\mathrm{b}}$ \\
\hline \multirow[t]{8}{*}{9} & Control & $1.4^{\mathrm{g}}$ & $1.1^{\mathrm{c}}$ & $1.0^{\mathrm{ab}}$ \\
\hline & $\mathrm{Ch}$ & $7.8^{\mathrm{h}}$ & $8.1^{\mathrm{d}}$ & $7.0^{\mathrm{g}}$ \\
\hline & CEO $0.2 \%$ & $2.2^{\mathrm{g}}$ & $2.1^{\mathrm{c}}$ & $2.0^{\mathrm{ab}}$ \\
\hline & CEO $0.4 \%$ & $1.8^{\mathrm{g}}$ & $1.0^{\mathrm{c}}$ & $1.5^{\mathrm{ab}}$ \\
\hline & CEO $0.6 \%$ & $1.2^{\mathrm{g}}$ & $1.0^{\mathrm{c}}$ & $1.0^{\mathrm{ab}}$ \\
\hline & Ch-CEO $0.2 \%$ & $8.0^{\mathrm{h}}$ & $8.5^{\mathrm{d}}$ & $8.0^{\mathrm{g}}$ \\
\hline & Ch-CEO 0.4\% & $8.4^{\mathrm{h}}$ & $8.4^{\mathrm{d}}$ & $8.2^{\mathrm{g}}$ \\
\hline & Ch-CEO 0.6\% & $8.7^{\mathrm{h}}$ & $8.4^{\mathrm{d}}$ & $8.2^{\mathrm{g}}$ \\
\hline
\end{tabular}

Any two means in the same column followed by the same letter are not significantly $(p>0.05)$ different from Duncan's multiple range tests. Ch: Chitosan, CEO: Cumin essential oil.

\section{Conclusions}

The results of this study showed that the combined use of chitosan and CEO prevented the growth of spoilage and foodborne pathogenic microbial, delayed lipid oxidation and increased shelf life of chicken meat at $4^{\circ} \mathrm{C}$. The samples wrapped with $\mathrm{Ch}$ and $\mathrm{CEO} 0.4$ and $0.6 \%$ was the most effective of all, inhibiting the growth of the microbial spoilage, decreasing lipid oxidation of 9 days. In conclusion, the use of antimicrobial coatings has been indicated to be an effective method to preserve microbial and sensory quality of meat. On the other hand, using various preservative factors in small amounts is a preferred approach, because it has physicochemical characteristics, sensory properties and economic advantages.

\section{References}

Alizadeh-Sani, M., Khezerlou, A., \& Ehsani, A. (2018). Fabrication and characterization of the bionanocomposite film based on whey protein biopolymer loaded with $\mathrm{TiO} 2$ nanoparticles, cellulose nanofibers and rosemary essential oil. Industrial crops and products, 124, 300-315. 
Alizadeh-Sani, M., Mohammadian, E., \& McClements, D. J. (2020). Eco-friendly active packaging consisting of nanostructured biopolymer matrix reinforced with $\mathrm{TiO} 2$ and essential oil: Application for preservation of refrigerated meat. Food chemistry, 322, 126782.

Allahghadri, T., Rasooli, I., Owlia, P., Nadooshan, M. J., Ghazanfari, T., Taghizadeh, M., \& Astaneh, S. D. A. (2010). Antimicrobial property, antioxidant capacity, and cytotoxicity of essential oil from cumin produced in Iran. Journal of food science, 75(2), H54-H61.

Arkoun, M., Daigle, F., Heuzey, M.C., \& Ajji, A. (2017). Mechanism of action of electrospun chitosan-based nanofibers against meat spoilage and pathogenic bacteria. Molecules, 22(4), 585.

Azizi-lalabadi, M., Alizadeh-Sani, M., Divband, B., Ehsani, A., \& McClements, D. J. (2020). Nanocomposite films consisting of functional nanoparticles ( $\mathrm{TiO} 2$ and $\mathrm{ZnO}$ ) embedded in 4A-Zeolite and mixed polymer matrices (gelatin and polyvinyl alcohol). Food Research International, 137, 109716.

Azlin-Hasim, S., Cruz-Romero, M. C., Morris, M. A., Cummins, E., \& Kerry, J. P. (2018). Spray coating application for the development of nanocoated antimicrobial low-density polyethylene films to increase the shelf life of chicken breast fillets. Food Science and Technology International, 24(8), 688-698.

Babuskin, S., Babu, P. A. S., Sasikala, M., Sabina, K., Archana, G., Sivarajan, M., \& Sukumar, M. (2014). Antimicrobial and antioxidant effects of spice extracts on the shelf life extension of raw chicken meat. International journal of food microbiology, 171, 32-40.

Bagheri, V., Ghanbarzadeh, B., Ayaseh, A., Ostadrahimi, A., Ehsani, A., Alizadeh-Sani, M., \& Adun, P. A. (2019). The optimization of physico-mechanical properties of bionanocomposite films based on gluten/carboxymethyl cellulose/cellulose nanofiber using response surface methodology. Polymer Testing, 78, 105989. Chantarasataporn, P., Tepkasikul, P., Kingcha, Y., Yoksan, R., Pichyangkura, R., Visessanguan, W., \& Chirachanchai, S. (2014). Water-based oligochitosan and nanowhisker chitosan as potential food preservatives for shelf-life extension of minced pork. Food chemistry, 159, 463-470.

Chouliara, E., Karatapanis, A., Savvaidis, I., \& Kontominas, M. (2007). Combined effect of oregano essential oil and modified atmosphere packaging on shelf-life extension of fresh chicken breast meat, stored at 4 C. Food Microbiology, 24(6), 607-617.

Fan, W., Sun, J., Chen, Y., Qiu, J., Zhang, Y., \& Chi, Y. (2009). Effects of chitosan coating on quality and shelf life of silver carp during frozen storage. Food chemistry, 115(1), 6670.

García-Díez, J., Alheiro, J., Falco, V., Fraqueza, M. J., \& Patarata, L. (2017). Chemical characterization and antimicrobial properties of herbs and spices essential oils against pathogens and spoilage bacteria associated to dry-cured meat products. Journal of EssEntial oil rEsEarch, 29(2), 117-125.

Georgantelis, D., Ambrosiadis, I., Katikou, P., Blekas, G., \& Georgakis, S. A. (2007). Effect of rosemary extract, chitosan and $\alpha$ tocopherol on microbiological parameters and lipid oxidation of fresh pork sausages stored at 4 C. Meat science, 76(1), 172-181.

Giatrakou, V., Ntzimani, A., \& Savvaidis, I. (2010). Effect of chitosan and thyme oil on a ready to cook chicken product. Food Microbiology, 27(1), 132-136.

Jirovetz, L., Buchbauer, G., Stoyanova, A. S., Georgiev, E. V., \& Damianova, S. T. (2005). Composition, quality control and antimicrobial activity of the essential oil of cumin (Cuminum cyminum L.) seeds from Bulgaria that had been stored for up to 36 years. International journal of food science \& technology, 40(3), 305-310. 
Karakaya, S., \& Simsşek, S. (2011). Changes in total polar compounds, peroxide value, total phenols and antioxidant activity of various oils used in deep fat frying. Journal of the American Oil Chemists' Society, 88(9), 1361-1366.

Kedia, A., Prakash, B., Mishra, P. K., \& Dubey, N. (2014). Antifungal and antiaflatoxigenic properties of Cuminum cyminum (L.) seed essential oil and its efficacy as a preservative in stored commodities. International journal of food microbiology, 168, 1-7.

Lomate, G. B., Dandi, B., \& Mishra, S. (2018). Development of antimicrobial LDPE/Cu nanocomposite food packaging film for extended shelf life of peda. Food packaging and shelf life, 16, 211-219.

Mahdizadeh, A., Shahidi, S. A., Shariatifar, N., Shiran, M. R., \& Ghorbani Hassan Saraei, A. (2020). Preparation and evaluation of chitosan-zein film containing free and encapsulated ethanol extract of kak kosh biabani Pulicaria gnaphalodes (Vent.) Boiss. Journal of Medicinal Plants, 19(75), 223238.

Martins, J. T., Cerqueira, M. A., \& Vicente, A. A. (2012). Influence of $\alpha$-tocopherol on physicochemical properties of chitosanbased films. Food hydrocolloids, 27(1), 220227.

Noshirvani, N., Hong, W., Ghanbarzadeh, B., Fasihi, H., \& Montazami, R. (2018). Study of cellulose nanocrystal doped starchpolyvinyl alcohol bionanocomposite films. International journal of biological macromolecules, 107, 2065-2074.

Oroojalian, F., Kasra-Kermanshahi, R., Azizi, M., \& Bassami, M. R. (2010). Phytochemical composition of the essential oils from three Apiaceae species and their antibacterial effects on food-borne pathogens. Food chemistry, 120(3), 765770.

Peng, Y., Li, Y., \& Yin, L. (2013). Effects of edible coatings on some quality parameters of Chinese water chestnut (Eleocharis tuberosa) during storage. International journal of food science \& technology, 48(7), 1404-1409.

Petrou, S., Tsiraki, M., Giatrakou, V., \& Savvaidis, I. (2012). Chitosan dipping or oregano oil treatments, singly or combined on modified atmosphere packaged chicken breast meat. International journal of food microbiology, 156(3), 264-271.

Plascencia-Jatomea, M., Viniegra, G., Olayo, R., Castillo-Ortega, M. M., \& Shirai, K. (2003). Effect of chitosan and temperature on spore germination of Aspergillus niger. Macromolecular Bioscience, 3(10), 582586.

Rebey, I. B., Bourgou, S., Debez, I. B. S., Karoui, I. J., Sellami, I. H., Msaada, K., Limam, F., \& Marzouk, B. (2012). Effects of extraction solvents and provenances on phenolic contents and antioxidant activities of cumin (Cuminum cyminum L.) seeds. Food and Bioprocess Technology, 5(7), 2827-2836.

Rebey, I. B., Jabri-Karoui, I., HamrouniSellami, I., Bourgou, S., Limam, F., \& Marzouk, B. (2012). Effect of drought on the biochemical composition and antioxidant activities of cumin (Cuminum cyminum L.) seeds. Industrial crops and products, 36(1), 238-245.

Rhim, J.-W., Hong, S.-I., Park, H.-M., \& Ng, P. K. (2006). Preparation and characterization of chitosan-based nanocomposite films with antimicrobial activity. Journal of agricultural and food chemistry, 54(16), 5814-5822.

Ribeiro-Santos, R., Andrade, M., de Melo, N. R., \& Sanches-Silva, A. (2017). Use of essential oils in active food packaging: Recent advances and future trends. Trends in food science \& technology, 61, 132-140.

Ruby, K., Chauhan, R., Sharma, S., \& Dwivedi, J. (2012). Polypharmacological activities of Bergenia species. International Journal of Pharmaceutical Sciences Review and Research, 13(1), 100-110.

Sadeghi, E., Akhondzadeh-Basti, A., Noori, N., Khanjari, A., \& Partovi, R. (2013). Effect of Cuminum cyminum $\mathrm{L}$. essential oil and 
Lactobacillus acidophilus (a probiotic) on Staphylococcus aureus during the manufacture, ripening and storage of white brined cheese. Journal of food processing and preservation, 37(5), 449-455.

Salari, M., Khiabani, M. S., Mokarram, R. R., Ghanbarzadeh, B., \& Kafil, H. S. (2018). Development and evaluation of chitosan based active nanocomposite films containing bacterial cellulose nanocrystals and silver nanoparticles. Food hydrocolloids, 84, 414-423.

Sani, M. A., Ehsani, A., \& Hashemi, M. (2017). Whey protein isolate/cellulose nanofibre/TiO2 nanoparticle/rosemary essential oil nanocomposite film: Its effect on microbial and sensory quality of lamb meat and growth of common foodborne pathogenic bacteria during refrigeration. International journal of food microbiology, 251, 8-14.

Shekarforoush, S. S., Basiri, S., Ebrahimnejad, H., \& Hosseinzadeh, S. (2015). Effect of chitosan on spoilage bacteria, Escherichia coli and Listeria monocytogenes in cured chicken meat. International journal of biological macromolecules, 76, 303-309.

Siripatrawan, U., \& Noipha, S. (2012). Active film from chitosan incorporating green tea extract for shelf life extension of pork sausages. Food hydrocolloids, 27(1), 102108.

Soultos, N., Tzikas, Z., Abrahim, A., Georgantelis, D., \& Ambrosiadis, I. (2008). Chitosan effects on quality properties of Greek style fresh pork sausages. Meat science, 80(4), 1150-1156.

Tharanathan, R. (2003). Biodegradable films and composite coatings: past, present and future. Trends in food science \& technology, 14(3), 71-78.

Vasilatos, G., \& Savvaidis, I. (2013). Chitosan or rosemary oil treatments, singly or combined to increase turkey meat shelf-life. International journal of food microbiology, 166(1), 54-58.
Wang, Q., Tian, F., Feng, Z., Fan, X., Pan, Z., \& Zhou, J. (2015). Antioxidant activity and physicochemical properties of chitosan films incorporated with Lycium barbarum fruit extract for active food packaging. International journal of food science \& technology, 50(2), 458-464.

Xiong, Z., Sun, D.-W., Pu, H., Xie, A., Han, Z., \& Luo, M. (2015). Non-destructive prediction of thiobarbituric acid reactive substances (TBARS) value for freshness evaluation of chicken meat using hyperspectral imaging. Food chemistry, 179, 175-181.

Xu, Y., Kim, K. M., Hanna, M. A., \& Nag, D. (2005). Chitosan-starch composite film: preparation and characterization. Industrial crops and products, 21(2), 185-192.

Yuan, G., Chen, X., \& Li, D. (2016). Chitosan films and coatings containing essential oils: The antioxidant and antimicrobial activity, and application in food systems. Food Research International, 89, 117-128.

\section{Acknowledgement}

This work was a part of funded MS thesis in School of Public Health at Tehran University of Medical Sciences. The authors would like to thank Tehran University of Medical Sciences for providing financial support, grant no. 94-04-2730973. 